\title{
GROWTH RESPONSES OF STRAWBERRY (FRAGARIA $\times$ ANANASSA DUCH.) PLANTS GROWN AT DIFFERENT PLANTING DENSITY USING PVC PIPE UNDER PROTECTED CULTIVATION
}

\author{
Vikas Kumar Sharma* and Anil Kumar Godara \\ Department of Horticulture, CCS Haryana Agricultural University, Hisar-125004, Haryana
}

Keywords: Artificial media, Growth, Pipe diameter, Plant geometry, Sweet Charlie

\begin{abstract}
Production of strawberry cv. Sweet Charlie under soilless system (Horizontal and A-shape structures) at six different planting densities using two diameters of PVC pipes in a actively ventilated poly house was attempted. Significant differences were observed in growth parameters, namely number of leaves, petiole length, plant height, plant spread and crown diameter. The results showed that the plants grown at $\mathrm{D}_{3}(20$ plants $\left./ \mathrm{m}^{2}\right)$ significantly increased the number of leaves (9.76 and 12.49) and plant spread (24.44 and 25.69 $\mathrm{cm})$ compared to other planting densities. The planting density significantly influenced the petiole length and plant height also in strawberry. The maximum petiole length $(8.43$ and $8.64 \mathrm{~cm})$ and plant height $(13.92$ and $15.31 \mathrm{~cm})$ were recorded from $\mathrm{D}_{3}\left(12\right.$ plants $\left./ \mathrm{m}^{2}\right)$, however non-significant difference was observed between $\mathrm{D}_{3}$ and $\mathrm{D}_{4}$. In future, these experimental results will prove very useful to find out most suitable plant geometry for better growth of strawberry.
\end{abstract}

\section{Introduction}

The modern cultivated strawberry (Fragaria $\times$ ananassa Duch., Rosaceae) is one of the most widely distributed soft fruits in the world due to its genotypic diversity, highly heterozygous nature and broad range of environmental adaptations (Childers et al. 1995, Sharma and Sharma 2004). Strawberries are widely considered a high value crop, so the use of new technologies related such as poly house, low tunnels, plastic mulches, plastic films and shading screens are increasing for obtaining higher productivity and quality of fruits. Due to its health properties, strawberry is being promoted for year-round production and this has been made possible through soilless cultivation. Greenhouse structures are expensive to set up and the plant size of strawberry is small, to make the greenhouse cost effective the vertical space needs to be utilized for high productivity by modifying the plant geometry (Linsley-Noakes et al. 2006). The increased demand for strawberries round the year is met through soilless cultivation (Morgan 2006). The volume and dimensions of containers not only affect aeration and water holding capacity of the media but also determine the production costs (Cantliffe et al. 2001). The yield of the strawberry is mainly related to the number of plants rather than the area. The optimum utilization of the greenhouse has been reported from various places across the world. The planting density can be increased three to four times by using a vertical system (Ozeker et al. 1999). The need of high density planting and appropriate plant geometry have become even more important when the crop area under cultivation is reducing with the increasing population and economic development. There is a challenge to meet the nutritional requirement from smaller area that too under changing global climate. Therefore, it is important to find out the most suitable plant geometry as well as optimal planting density within the system to maximize the utilization and distribution of light for strawberry cultivation under poly house conditions.

*Author for correspondence: <vksharma087@gmail.com>. 


\section{Materials and Methods}

The experiment was conducted at Hi-tech greenhouse of Department of Horticulture, CCS Haryana Agricultural University, Hisar located at $215.2 \mathrm{~m}$ above sea level with co-ordinates of $29^{\circ}$ $10^{\prime} \mathrm{N}$ latitude and $75^{\circ} 46^{\prime} \mathrm{E}$ longitudes and 215-218 m from mean sea level in western Haryana during 2013-14 and 2014-15 growing seasons. The plants of strawberry cv. Sweet Charlie were planted under natural light condition during the first week of October. A set of PVC pipes of 1.5-2.0 m length was installed in an area of $2.0 \times 1.0 \mathrm{~m}$ in both horizontal [12, 16 and 32 plants $/ \mathrm{m}^{2}$ (Figs 1, 5, 6)] and A-shape [20, 24, 24 and 28 plants $/ \mathrm{m}^{2}$ (Figs 2-4)] growing systems. Holes $(30 \mathrm{~mm})$ were made with the help of electric hand drill machine at $25 \mathrm{~cm}$ distance. In horizontal system, first plant was placed at $12.5 \mathrm{~cm}$, while in A- shape growing system first plant was placed $30 \mathrm{~cm}$ above from the bottom end. The PVC pipes were filled with the mixture of artificial media (3:1:1, cocopeat + perlite + vermicompost). The fertigation system was open drip irrigation (with no circulation) using drippers installed on each hole in horizontal growing system and at the top of each PVC pipe in A-shape growing system. The transplanted plants were kept under uniform condition in poly-house during the study period where all the management practices were carried out as per the package of practices.
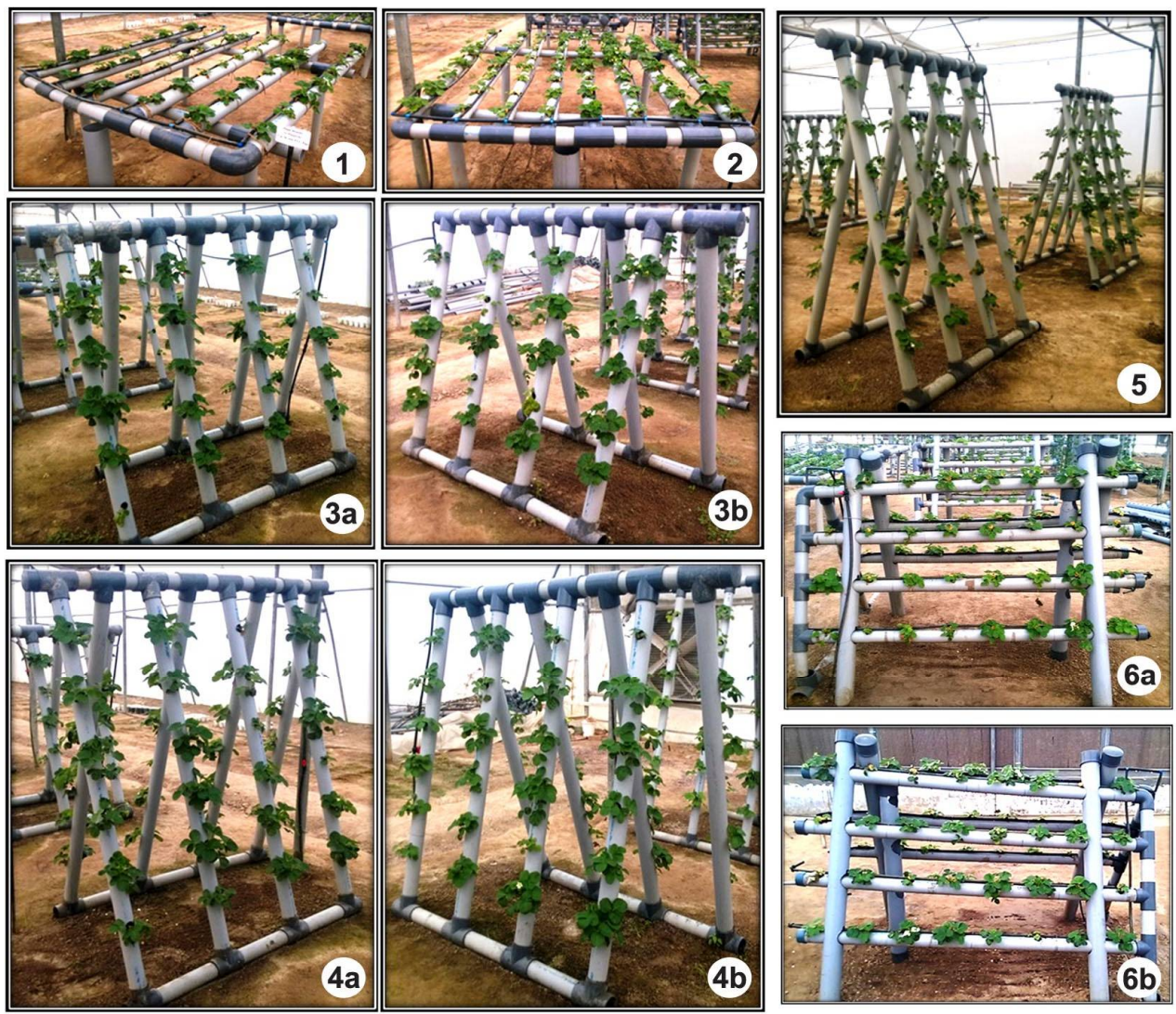

Figs 1-6. Strawberry plants in different structures. 1. 12 plants $/ \mathrm{m}^{2}(75 \mathrm{~mm}$ and $90 \mathrm{~mm}), 2.16$ plants $/ \mathrm{m}^{2}(75$ $\mathrm{mm}$ and $90 \mathrm{~mm})$. 3a. 20 plants $/ \mathrm{m}^{2}(75 \mathrm{~mm})$. 3b. 20 plants $/ \mathrm{m}^{2}(90 \mathrm{~mm}), 4 \mathrm{a} .24$ plants $/ \mathrm{m}^{2}(75 \mathrm{~mm}), 4$ b. 24 plants $/ \mathrm{m}^{2}(90 \mathrm{~mm}), 5.28$ plants $/ \mathrm{m}^{2}(75 \mathrm{~mm}$ and $90 \mathrm{~mm}), 6$ a. 32 plants $/ \mathrm{m}^{2}(75 \mathrm{~mm})$ and $6 \mathrm{~b} .32 \mathrm{plants} / \mathrm{m}^{2}$ (90 mm). 
The number of leaves per plant was counted from the time of transfer to the end of growing season (October-March) at fortnightly interval and the average number of leaves per plant was calculated at each observation. Petiole length was calculated by measuring three randomly selected leaves per plant with the help of scale. The average of length was expressed as average petiole length in centimeters. The height of the plant was measured individually with a measuring scale from the crown level to the apex of primary leaves and result expressed as average height in centimeters.

The plant spread was calculated by measuring the canopy of plant in East - West (E-W) and North - South (N-S) direction with the scale and the average of both was expressed as plant spread in centimeters. The diameter of crown of plant was measured with the help of Vernier Calipers and expressed in millimeters.

The data were analyzed according to the procedure for analysis of completely randomized design (CRD) as given by Panse and Sukhtme (1984). The overall significance of difference among the treatments was tested, using critical differences (C.D.) at $5 \%$ level of significance. The results were statistically analyzed with the help of a windows-based computer package OPSTAT (Sheoran et al. 1998).

\section{Results and Discussion}

The number of leaves per plant varied significantly with different planting density, PVC pipe diameter and pair-wise interactions between the treatments (Table 1).

Table 1. Effect of different plant densities and PVC pipe diameter on number of leaves per plant in strawberry cv. Sweet Charlie.

\begin{tabular}{|c|c|c|c|c|c|c|}
\hline \multirow{3}{*}{$\begin{array}{l}\text { Planting } \\
\text { density }\end{array}$} & \multicolumn{6}{|c|}{ PVC pipe diameter } \\
\hline & \multicolumn{3}{|c|}{$2013-2014$} & \multicolumn{3}{|c|}{$2014-2015$} \\
\hline & $75 \mathrm{~mm}$ & $90 \mathrm{~mm}$ & Mean & $75 \mathrm{~mm}$ & $90 \mathrm{~mm}$ & Mean \\
\hline 12 plants $/ \mathrm{m}^{2}\left(\mathrm{D}_{1}\right)$ & 8.11 & 9.33 & 8.72 & 10.82 & 12.65 & 11.73 \\
\hline 16 plants $/ \mathrm{m}^{2}\left(\mathrm{D}_{2}\right)$ & 7.89 & 8.02 & 7.96 & 10.73 & 11.77 & 11.25 \\
\hline 20 plants $/ \mathrm{m}^{2}\left(\mathrm{D}_{3}\right)$ & 9.24 & 10.29 & 9.76 & 11.74 & 13.23 & 12.49 \\
\hline 24 plants $/ \mathrm{m}^{2}\left(\mathrm{D}_{4}\right)$ & 8.89 & 9.51 & 9.20 & 11.32 & 12.80 & 12.06 \\
\hline 28 plants $/ \mathrm{m}^{2}\left(\mathrm{D}_{5}\right)$ & 8.60 & 9.33 & 8.96 & 10.85 & 12.72 & 11.78 \\
\hline 32 plants $/ \mathrm{m}^{2}\left(\mathrm{D}_{6}\right)$ & 7.73 & 7.99 & 7.86 & 9.50 & 11.63 & 10.57 \\
\hline Mean & 8.41 & 9.08 & 8.74 & 10.83 & 12.47 & 11.65 \\
\hline \multirow{3}{*}{$\mathrm{CD}(\mathrm{p}=0.05)$} & \multicolumn{3}{|c|}{ Planting density $=0.36$} & \multicolumn{3}{|c|}{ Planting density $=0.35$} \\
\hline & \multicolumn{3}{|c|}{ PVC pipe diameter $=0.21$} & \multicolumn{3}{|c|}{ PVC pipe diameter $=0.20$} \\
\hline & \multicolumn{3}{|c|}{ Pl. den. $\times$ P. dia. $=0.51$} & \multicolumn{3}{|c|}{ Pl. den. $\times$ P. dia. $=0.49$} \\
\hline
\end{tabular}

The maximum number of leaves per plant (9.76 and 12.49) was obtained during 2013-14 and 2014-15, respectively from $\mathrm{D}_{3}\left(20\right.$ plants $\left./ \mathrm{m}^{2}\right)$, which was significantly higher than the remaining plant densities, whereas, the minimum number of leaves (7.86 and 10.57) per plant was recorded from highest planting density $\left(\mathrm{D}_{6}\right)$. The number of leaves per plant increased significantly with the increase in PVC pipe diameter and the plants grown in $90 \mathrm{~mm}$ PVC pipe produced higher number of leaves (9.08 and 12.47, respectively) than $75 \mathrm{~mm} \mathrm{PVC} \mathrm{pipe} \mathrm{(8.41} \mathrm{and} \mathrm{10.83,} \mathrm{respectively)} \mathrm{in}$ both the years (2013-14 and 2014-15) of study. The data recorded during the period of study revealed that the plants were grown at $\mathrm{D}_{3}$ in $90 \mathrm{~mm}$ PVC pipes resulted highest number of leaves (10.29 and 13.23) per plant, except $\mathrm{D}_{4}\left(24\right.$ plants $\left./ \mathrm{m}^{2}\right)$ in $90 \mathrm{~mm}$ PVC pipe (12.80) during 2014-15. 
The petiole length was significantly influenced by planting density and diameter of PVC pipe (Table 2). Among various densities, a significant increase in petiole length was observed at 20 plants $/ \mathrm{m}^{2}$, which produced maximum petiole length $(8.43$ and $8.64 \mathrm{~cm})$ and it was statistically at par with $\mathrm{D}_{4}(8.24$ and $8.33 \mathrm{~cm})$, whereas, shortest petiole was recorded from $\mathrm{D}_{2}(7.60$ and 7.40 $\mathrm{cm}$ ) in both growing seasons, respectively.

Table 2. Effect of different plant densities and PVC pipe diameter on petiole length $(\mathrm{cm})$ in strawberry cv. Sweet Charlie.

\begin{tabular}{|c|c|c|c|c|c|c|}
\hline \multirow{3}{*}{$\begin{array}{l}\text { Planting } \\
\text { density }\end{array}$} & \multicolumn{6}{|c|}{ PVC pipe diameter } \\
\hline & \multicolumn{3}{|c|}{$2013-2014$} & \multicolumn{3}{|c|}{$2014-2015$} \\
\hline & $75 \mathrm{~mm}$ & $90 \mathrm{~mm}$ & Mean & $75 \mathrm{~mm}$ & $90 \mathrm{~mm}$ & Mean \\
\hline 12 plants $/ \mathrm{m}^{2}\left(\mathrm{D}_{1}\right)$ & 7.84 & 8.37 & 8.10 & 7.80 & 7.85 & 7.82 \\
\hline 16 plants $/ \mathrm{m}^{2}\left(\mathrm{D}_{2}\right)$ & 7.44 & 7.76 & 7.60 & 7.24 & 7.56 & 7.40 \\
\hline 20 plants $/ \mathrm{m}^{2}\left(\mathrm{D}_{3}\right)$ & 8.09 & 8.76 & 8.43 & 8.44 & 8.85 & 8.64 \\
\hline 24 plants $/ \mathrm{m}^{2}\left(\mathrm{D}_{4}\right)$ & 8.02 & 8.47 & 8.24 & 7.96 & 8.70 & 8.33 \\
\hline 28 plants $/ \mathrm{m}^{2}\left(\mathrm{D}_{5}\right)$ & 7.86 & 8.41 & 8.14 & 7.94 & 8.44 & 8.19 \\
\hline 32 plants $/ \mathrm{m}^{2}\left(\mathrm{D}_{6}\right)$ & 7.83 & 8.01 & 7.92 & 7.38 & 7.80 & 7.59 \\
\hline \multirow[t]{2}{*}{ Mean } & 7.85 & 8.30 & 8.07 & 7.79 & 8.20 & 8.00 \\
\hline & \multicolumn{3}{|c|}{ Planting density $=0.41$} & \multicolumn{3}{|c|}{ Planting density $=0.34$} \\
\hline \multirow[t]{2}{*}{$\mathrm{CD}(\mathrm{P}=0.05)$} & \multicolumn{3}{|c|}{ PVC pipe diameter $=0.24$} & \multicolumn{3}{|c|}{ PVC pipe diameter $=0.20$} \\
\hline & \multicolumn{3}{|c|}{ Pl. den. $\times$ P. dia. $=$ N.S. } & \multicolumn{3}{|c|}{ Pl. den. $\times$ P. dia. $=$ N.S. } \\
\hline
\end{tabular}

N.S. $=$ Non-significant

Plants grown in $90 \mathrm{~mm}$ PVC pipe produced higher petiole length $(8.30$ and $8.20 \mathrm{~cm})$ compared to plants grown in $75 \mathrm{~mm}$ PVC pipe $(7.85$ and $7.79 \mathrm{~cm})$, respectively. The interactive effects of plant density and pipe diameter were found non-significant. However, numerically maximum petiole length $\left(8.76\right.$ and $8.85 \mathrm{~cm}$ ) was observed at 20 plants $/ \mathrm{m}^{2}$, when grown in $90 \mathrm{~mm}$ PVC pipe.

Data pertaining to plant height as influenced by PVC pipe diameter and plant density are presented in Table 3. The plants grown at 20 plants $/ \mathrm{m}^{2}$ density produced maximum plant height (13.92 and $15.31 \mathrm{~cm})$, except $\mathrm{D}_{4}(13.53 \mathrm{~cm})$ during 2013-14, while minimum plant height was observed at 32 plants $/ \mathrm{m}^{2}(12.70$ and $13.24 \mathrm{~cm})$ which was statistically at par with $\mathrm{D}_{2}(12.92$ and $13.33 \mathrm{~cm}$ ) during both the growing seasons, respectively. The plants grown in $90 \mathrm{~mm}$ PVC pipes were more tall $(13.66$ and $14.36 \mathrm{~cm})$ than small size pipes $(12.89 \mathrm{~cm}$ and $13.66 \mathrm{~cm})$, respectively in 2013-14 and 2014-15. The perusal of data showed that interactive effect of treatments did not differ significantly. However, the plant height was more $(14.44 \mathrm{~cm}$ and $15.82 \mathrm{~cm})$ in plants grown in $90 \mathrm{~mm}$ PVC pipe at 20 plants $/ \mathrm{m}^{2}$ density.

The data concerning plant spread as affected by different planting densities and PVC pipe diameter are presented in Table 4. Significant difference was recorded between the two different sizes of pipes and among the all plant densities. During 2013-14, the plants grown at $\mathrm{D}_{3}$ showed maximum plant spread $(24.44 \mathrm{~cm})$, which was statistically at par with $\mathrm{D}_{1}(23.62 \mathrm{~cm})$, whereas, the minimum plant spread $(21.34 \mathrm{~cm})$ was observed from the plants grown at $\mathrm{D}_{6}\left(32 \mathrm{plants} / \mathrm{m}^{2}\right)$. Similar trend was observed during the second year of experiment. In both growing seasons $90 \mathrm{~mm}$ pipe diameter gave higher plant spread $(23.76$ and $25.25 \mathrm{~cm}$ ) as compared to $75 \mathrm{~mm}$ diameter $(21.52$ and $22.36 \mathrm{~cm})$ during 2013-14 and 2014-15, respectively. The interactions between 
planting densities and pipe diameter were also found to be significant. The plants grown at 20 plants $/ \mathrm{m}^{2}$ in $90 \mathrm{~mm}$ PVC pipe resulted maximum plant spread $(26.17$ and $27.82 \mathrm{~cm})$ and were found superior to all the treatments except at $\mathrm{D}_{1}$ in $90 \mathrm{~mm}$ PVC pipe during 2013-14.

Table 3. Effect of different plant densities and PVC pipe diameter on plant height $(\mathrm{cm})$ in strawberry cv. Sweet Charlie.

\begin{tabular}{|c|c|c|c|c|c|c|}
\hline \multirow{3}{*}{$\begin{array}{l}\text { Planting } \\
\text { density }\end{array}$} & \multicolumn{6}{|c|}{ PVC pipe diameter } \\
\hline & \multicolumn{3}{|c|}{ 2013-2014 } & \multicolumn{3}{|c|}{ 2014-2015 } \\
\hline & $75 \mathrm{~mm}$ & $90 \mathrm{~mm}$ & Mean & $75 \mathrm{~mm}$ & $90 \mathrm{~mm}$ & Mean \\
\hline 12 plants $/ \mathrm{m}^{2}\left(\mathrm{D}_{1}\right)$ & 12.77 & 13.59 & 13.18 & 13.22 & 13.95 & 13.59 \\
\hline 16 plants $/ \mathrm{m}^{2}\left(\mathrm{D}_{2}\right)$ & 12.76 & 13.07 & 12.92 & 12.93 & 13.72 & 13.33 \\
\hline 20 plants $/ \mathrm{m}^{2}\left(\mathrm{D}_{3}\right)$ & 13.40 & 14.44 & 13.92 & 14.80 & 15.82 & 15.31 \\
\hline 24 plants $/ \mathrm{m}^{2}\left(\mathrm{D}_{4}\right)$ & 12.98 & 14.09 & 13.53 & 14.34 & 15.09 & 14.72 \\
\hline 28 plants $/ \mathrm{m}^{2}\left(\mathrm{D}_{5}\right)$ & 12.87 & 13.88 & 13.38 & 13.76 & 13.99 & 13.88 \\
\hline 32 plants $/ \mathrm{m}^{2}\left(\mathrm{D}_{6}\right)$ & 12.54 & 12.87 & 12.70 & 12.89 & 13.59 & 13.24 \\
\hline Mean & 12.89 & 13.66 & 13.27 & 13.66 & 14.36 & 14.01 \\
\hline \multirow{3}{*}{$\mathrm{CD}(\mathrm{p}=0.05)$} & \multicolumn{3}{|c|}{ Planting density $=0.45$} & \multicolumn{3}{|c|}{ Planting density $=0.41$} \\
\hline & \multicolumn{3}{|c|}{ PVC pipe diameter $=0.26$} & \multicolumn{3}{|c|}{ PVC pipe diameter $=0.24$} \\
\hline & \multicolumn{3}{|c|}{ Pl. den. $\times$ P. dia. $=$ N.S. } & \multicolumn{3}{|c|}{ Pl. den. $\times$ P. dia. $=$ N.S. } \\
\hline
\end{tabular}

N.S. - Non-significant.

Table 4. Effect of different plant densities and PVC pipe diameter on plant spread $(\mathrm{cm})$ in strawberry cv. Sweet Charlie.

\begin{tabular}{|c|c|c|c|c|c|c|}
\hline \multirow{3}{*}{$\begin{array}{l}\text { Planting } \\
\text { density }\end{array}$} & \multicolumn{6}{|c|}{ PVC pipe diameter } \\
\hline & \multicolumn{3}{|c|}{$2013-2014$} & \multicolumn{3}{|c|}{$2014-2015$} \\
\hline & $75 \mathrm{~mm}$ & $90 \mathrm{~mm}$ & Mean & $75 \mathrm{~mm}$ & $90 \mathrm{~mm}$ & Mean \\
\hline 12 plants $/ \mathrm{m}^{2}\left(\mathrm{D}_{1}\right)$ & 21.82 & 25.41 & 23.62 & 23.40 & 26.51 & 24.96 \\
\hline 16 plants $/ \mathrm{m}^{2}\left(\mathrm{D}_{2}\right)$ & 20.78 & 22.26 & 21.52 & 21.42 & 24.15 & 22.78 \\
\hline 20 plants $/ \mathrm{m}^{2}\left(\mathrm{D}_{3}\right)$ & 22.72 & 26.17 & 24.44 & 23.55 & 27.82 & 25.69 \\
\hline 24 plants $/ \mathrm{m}^{2}\left(\mathrm{D}_{4}\right)$ & 21.69 & 23.96 & 22.83 & 23.16 & 25.46 & 24.31 \\
\hline 28 plants $/ \mathrm{m}^{2}\left(\mathrm{D}_{5}\right)$ & 21.55 & 22.62 & 22.09 & 21.75 & 24.44 & 23.09 \\
\hline 32 plants $/ \mathrm{m}^{2}\left(\mathrm{D}_{6}\right)$ & 20.55 & 22.13 & 21.34 & 20.87 & 23.12 & 22.00 \\
\hline Mean & 21.52 & 23.76 & 22.64 & 22.36 & 25.25 & 23.80 \\
\hline \multirow{3}{*}{$\mathrm{CD}(\mathrm{p}=0.05)$} & \multicolumn{3}{|c|}{ Planting density $=0.69$} & \multicolumn{3}{|c|}{ Planting density $=0.62$} \\
\hline & \multicolumn{3}{|c|}{ PVC pipe diameter $=0.40$} & \multicolumn{3}{|c|}{ PVC pipe diameter $=0.36$} \\
\hline & \multicolumn{3}{|c|}{ Pl. den. $\times$ P. dia. $=0.97$} & \multicolumn{3}{|c|}{ Pl. den. $\times$ P. dia. $=0.88$} \\
\hline
\end{tabular}

From the perusal of data in Table 5, it is evident that planting density, PVC pipe diameter and the interactions between the variants influenced significantly the crown diameter in strawberry. During 2013-14, the maximum crown diameter $(15.33 \mathrm{~mm})$ was obtained from the plants grown at $\mathrm{D}_{1}$ followed by $\mathrm{D}_{2}(14.72 \mathrm{~mm})$, while minimum crown diameter $(12.79 \mathrm{~mm})$ was recorded at $\mathrm{D}_{5}$ followed by $\mathrm{D}_{4}(13.83 \mathrm{~mm})$. The trend was similar during 2014-15 and the maximum crown diameter $(17.08 \mathrm{~mm})$ was recorded at 12 plants $/ \mathrm{m}^{2}$, which were significantly superior to all the other planting densities, whereas, the minimum crown diameter $(13.26 \mathrm{~mm})$ was found at 28 
plants $/ \mathrm{m}^{2}$. Increasing trend in crown diameter was observed as PVC pipe size increased. In both growing seasons maximum crown diameter was observed in $90 \mathrm{~mm}$ PVC pipe (14.72 and 15.99 $\mathrm{mm}$ ) as compared to $75 \mathrm{~mm}$ PVC pipe (13.67 and $14.52 \mathrm{~mm}$ ), respectively. The plants grown at $\mathrm{D}_{1}$ in combination with $90 \mathrm{~mm}$ PVC pipe gave maximum crown diameter $(16.26$ and $17.73 \mathrm{~mm}$ ) and were found to be superior among all the treatments.

Table 5. Effect of different plant densities and PVC pipe diameter on crown diameter (mm) in strawberry cv. Sweet Charlie.

\begin{tabular}{|c|c|c|c|c|c|c|}
\hline \multirow{3}{*}{$\begin{array}{l}\text { Planting } \\
\text { density }\end{array}$} & \multicolumn{6}{|c|}{ PVC pipe diameter } \\
\hline & \multicolumn{3}{|c|}{ 2013-2014 } & \multicolumn{3}{|c|}{ 2014-2015 } \\
\hline & $75 \mathrm{~mm}$ & $90 \mathrm{~mm}$ & Mean & $75 \mathrm{~mm}$ & $90 \mathrm{~mm}$ & Mean \\
\hline 12 plants $/ \mathrm{m}^{2}\left(\mathrm{D}_{1}\right)$ & 14.39 & 16.26 & 15.33 & 16.43 & 17.73 & 17.08 \\
\hline 16 plants $/ \mathrm{m}^{2}\left(\mathrm{D}_{2}\right)$ & 13.98 & 15.45 & 14.72 & 15.30 & 17.05 & 16.17 \\
\hline 20 plants $/ \mathrm{m}^{2}\left(\mathrm{D}_{3}\right)$ & 13.73 & 14.62 & 14.17 & 14.39 & 16.15 & 15.27 \\
\hline 24 plants $/ \mathrm{m}^{2}\left(\mathrm{D}_{4}\right)$ & 13.58 & 14.08 & 13.83 & 13.62 & 14.60 & 14.11 \\
\hline 28 plants $/ \mathrm{m}^{2}\left(\mathrm{D}_{5}\right)$ & 12.48 & 13.10 & 12.79 & 12.86 & 13.66 & 13.26 \\
\hline 32 plants $/ \mathrm{m}^{2}\left(\mathrm{D}_{6}\right)$ & 13.87 & 14.83 & 14.35 & 14.53 & 16.75 & 15.64 \\
\hline Mean & 13.67 & 14.72 & 14.20 & 14.52 & 15.99 & 15.25 \\
\hline \multirow{3}{*}{$\mathrm{CD}(\mathrm{p}=0.05)$} & \multicolumn{3}{|c|}{ Planting density $=0.43$} & \multicolumn{3}{|c|}{ Planting density $=0.46$} \\
\hline & \multicolumn{3}{|c|}{ PVC pipe diameter $=0.25$} & \multicolumn{3}{|c|}{ PVC pipe diameter $=0.27$} \\
\hline & \multicolumn{3}{|c|}{ Pl. den. $\times$ P. dia. $=0.61$} & \multicolumn{3}{|c|}{ Pl. den. $\times$ P. dia. $=0.66$} \\
\hline
\end{tabular}

In the present investigation, the results revealed that the vegetative growth of strawberry plant was influenced significantly by planting density. The maximum number of leaves, petiole length, plant height and plant spread was observed in the plants grown at $\mathrm{D}_{3}\left(20 \mathrm{plants} / \mathrm{m}^{2}\right)$ with A-shape planting system, except petiole length and plant height 2013-14, whereas, maximum crown diameter was recorded at $\mathrm{D}_{1}\left(12\right.$ plants $\left./ \mathrm{m}^{2}\right)$ horizontal system. Vegetative growth of plants in terms of decreased at higher planting density during both the seasons. This might be due to the higher planting density increasing interplant competition for plant nutrients, which resulted reduced vegetative growth. Similar results were reported by Galletta and Himelrick (1990), Wilson and Dixon (1998) and Tariq et al. (2013) in strawberry. Paranjpe et al. (2008) reported that plants grown at higher planting density had smaller crowns and fewer leaves than lesser planting density. The present findings are also in close agreement with the results of De-Camacaro et al. (2004) and Linsley-Noakes et al. (2006), who recommended lower planting density for better growth in strawberry. The plant density turned out to have a great influence on growth in strawberry especially crown diameter (Jansen 1997). But contrasting results were postulated by Ahmad (2009) and Portela et al. (2012), according to them planting density had no significant influence on the morphological characters of strawberry.

Potentially, the PVC size (diameter) plays an important role in controlling the vegetative growth of the plant i.e. number of leaves, petiole length, plant height, plant spread and crown diameter, which significantly increased with the increase of PVC pipe diameter during both the years of investigation. The lesser growth in $75 \mathrm{~mm}$ PVC pipes might be due to with the growth of the plants the root development takes place and most of the space is occupied by vigorous root system of the plants, which reduces the aeration at higher planting density. These findings are in consonance to the findings of Cantliffe et al. (2008) and Cantliffe et al. (2003), who reported that larger volumes generally favor increased plant growth rates. NeSmith and Duval (1998) also reported the container size can affect growth of plants in soil less culture. 
For maximum utilization of the greenhouse area, A-shape growing system is found to be the best option for commercial production as well as home gardening. Among the planting densities, significant differences were observed in growth parameters mainly due to differences in the root aeration and inter-plant competition. Better root aeration and light availability resulted in higher photosynthesis rate and better growth of the plants in A-shape structures.

\section{References}

Ahmad MF 2009. Effect of planting density on growth and yield of strawberry. Ind. J. Hort. 66(1): 132-134.

Cantliffe DJ, Funes J, Jovicich E, Paranjpe A, Rodriguez J and Shaw N 2003. Media and containers for greenhouse soilless grown cucumbers, melons, peppers and strawberries. Acta Hort. 614: 199-203.

Cantliffe DJ, Shaw N, Jovicich E, Rodriguez JC, Secker I and Karchi Z 2001. Passive ventilated high-roof greenhouse production of vegetables in a humid, mild winter climate. Acta Hort. 559: 515-520.

Cantliffe DJ, Webb JE, Vansickle JJ and Shaw NL 2008. Potential profits from greenhouse-grown organic strawberries are greater than conventional greenhouse or field grown strawberries in Florida. Pro. Flo. Stat. Hort. Soc. 121: 208-213.

Childers NF, Morris JR and Sibbett GS 1995. Modern Fruit Science. Hort. Pub., Gainesville, Florida, USA.

De-Camacaro MEP, Camacaro GJ, Hadley P, Dennett MD, Battey NH and Carew JG 2004. Effect of plant density and initial crown size on growth, development and yield in strawberry cultivars Elsanta and Bolero. J. Hort. Sci. Biotech. 79(5): 739-746.

Galletta G and Himelrick D 1990. Small fruit management. Prentice Hall, New Jersey, USA.

Jansen WAGM 1997. Growing media and plant densities for strawberry tray plants. Acta Hort. 439: 457-460.

Linsley-Noakes G, Wilken L and Villiers S 2006. High density, vertical hydroponics growing system for strawberries. Acta Hort. 708: 365-370.

Morgan L 2006. Hydroponic strawberry production. A technical guide to the hydroponic production of strawberries. Suntec (NZ) Ltd, Tokomaru, New Zealand.

NeSmith D and Duval R 1998. The effect of container size. Hort Technol. 8(4): 495-498.

Ozeker E, Elter RZ, Tuzel Y, Gul A, Onal K and Tanrisever A, 1999. Investigation on the effect of different growing media on the yield and quality of strawberries grown in vertical black bags. Acta Hort. 486: 409-413.

Panse VG and Sukatme PV 1984. Statistical methods for Agricultural workers. Indian Council of Agricultural Research, New Delhi, p. 155.

Paranjpe AV, Cantliffe DJ, Stoffella PJ, Lamb EM and Powell CA 2008. Relationship of plant density to fruit yield of 'Sweet Charlie' strawberry grown in a pine bark soilless medium in a high-roof passively ventilated greenhouse. Scientia Hort. 115: 117-123.

Portela IP, Nogueirapeil RM, Rodrigues S and Carini F 2012. Plant density, growth, yield and fruit quality of strawberry 'Camino Real' in hydroponics. Revista Brasileira Fruticul. 34(3): 792-798.

Sharma VP and Sharma RR 2004. The Strawberry (New Delhi, India: Indian Council of Agricultural Research (ICAR).

Sheoran OP, Tonk DS, Kaushik LS, Hasija RC and Pannu RS 1998. Statistical Software Package for Agricultural Research Workers. Recent Advances in information theory, Statistics \& Computer Applications by D.S. Hooda \& R.C. Hasija Department of Mathematics Statistics, CCS HAU, Hisar. pp 139-143.

Tariq R, Qureshi KM, Hassan I, Rasheed M and Qureshi US 2013. Effect of planting density \& growing media on growth \& yield of strawberry. Pak. J. Agri. Res. 26(2): 113-123.

Wilson F and Dixon GR 1998. Strawberry growth and yield related to plant density using matted row husbandry. J. Hort. Sci. 63: 221-227.

(Manuscript received on 10 July, 2018; revised on 9 August, 2018) 